\title{
Natureza jurídica das bôlsas de valores no direito brasileiro
}

\author{
Oscar Barreto Filho \\ Docente-livre de Direito Comercial na \\ Faculdade de Direito da Universidade \\ de São Paulo.
}

\section{Capítulo I}

1. A origem das Bôlsas dé Comércio remonta às épocas mais longínquas. Costumam os escritores referirse à existência do "emporium", entre os gregos, e do "collegium mercatorum", entre os romanos, como sendo lugares onde se reuniam os comerciantes, para o exercício da mercadoria ${ }^{1}$. No entanto, outros autores são de opinião que a origem das Bôlsas se encontra nas "loggie" italianas e nas "lonjas" espanholas da idade média ${ }^{2}$. De qualquer modo, é certo que surgiram as Bôlsas espontâneamente, como locais de concentração da oferta e da procura de mercadorias e valores comerciais.

No tocante à palavra "Bôlsa", parece provir da cidade flamenga de Bruges, na qual, durante o século XII, uma família nobre - Van der Burse - assinalava o frontispício de sua casa com escudo d'armas, em que figuravam três bôlsas; por extensão, tal nome passou a designar uma praça contígua, que constituía o centro de reunião dos mercadores. Foi, contudo, em Antuérpia, no ano de 1531,

(1) MiChEL CARSOW, Les bourses de valeurs mobilières, Paris, 1932 , p. 5 .

(2) Alvarez Del Manzano, Bonilla y Miñana, apud A. Ro. DRIGUEZ SASTRE, Operaciones de Bolsa, vol. I, Madri, 1954, p. 6. 
que se fundou a primeira Bôlsa de caráter internacional ${ }^{3}$.

A organização moderna das Bôlsas teve início com a Bôlsa de Londres (1570), que em 1773 se converteu no Stock Exchange. As Bôlsas de Paris e Berlim desenvolveram-se mais lentamente, e sòmente nos fins do século xIx adquiriram importância mundial, o que, no século atual, sucedeu com a Bôlsa de Nova Iorque ${ }^{4}$.

Não há dúvida que o apogeu das Bôlsas de valores prende-se estreitamente ao desenvolvimento das sociedades anônimas, como meio de obter capitais, pois só a partir dêsse momento se pode falar na existência de verdadeiros mercados de valores mobiliários.

2. A palavra "Bôlsa" pode ser tomada em várias acepções; mister se faz distinguí-las, para evitar ulteriores dúvidas.

O eminente comercialista espanhol Joaguim Garrigues afirma que, "na linguagem corrente, emprega-se a palavra "Bôlsa" em quatro sentidos: para expressar o edifício ou lugar, o conjunto de operações de um dia determinado, o estado das operações bolsistas ("a Bôlsa sobe, ou baixa, ou está firme") e, finalmente, a instituição da bôlsa" ${ }^{5}$.

Sob o ponto de vista jurídico, oferece grande interêsse a última acepção, ou seja, considerada a Bôlsa como instituição reconhecida e regulada pelas leis. No entanto, como adverte o mesmo Garrigues, "a formulação de um conceito teórico da instituição of erece dificuldades. Costuma-se dizer que a Bôlsa é uma classe especial de mercado, que se diferencia dos demais por uma série de características: a organização corporativa, o fato de ser

(3) J. X. CaRvalho de Mendonça, Tratado de Direito Comercial Brasileiro, $3 .^{a}$ ed, vol. VI, parte II, Rio de Janeiro, 1930, n. 1.585, p. $280 / 281$.

(4) Harold G. Moulton, La Organización Financiera y el Sistema Económico, trad. espanhola, Buenos Aires, 1944, p. 294.

(5) J. GARRIGUES, Tratado de Derecho Mercantil, tomo I, vol. 1. ${ }^{\circ}$, Madrí, 1947, p. 73. 
frequentada por comerciantes, a circunstância de não se encontrarem presentes na Bôlsa os objetos sôbre os quais se contrata. Talvez os dois traços mais salientes da Bôlsa como mercado sejam a tipicidade dos negócios e a formação objetiva (impessoal) dos preços. Ambos os dados constituem manifestação evidente de uma mesma tendência para a objetivação das relações mercantis" ${ }^{6}$.

Não é êste o momento apropriado para discorrer sôbre a relevante função econômico-social desempenhada pelas Bôlsas, decorrente da influência que exercem sôbre o crédito público e a atividade geral dos negócios de um pais. Restrito, como é, o nosso trabalho à conceituação jurídica das Bôlsas, importa entrar desde logo no exame da matéria.

3. Sem anteciparmos, por ora, qualquer conclusão, podemos asseverar, com Rodriguez SASTre, que "Bôlsa é o estabelecimento especialmente organizado, onde se reúnem as pessoas que, acidental ou habitualmente, exercem o comércio, para contratar operações a que podem dar lugar todo gênero de valores públicos ou privados" "

$\mathrm{O}$ art. 64 do Código de Comércio Espanhol define: "Os estabelecimentos públicos legalmente autorizados, onde ordinàriamente se reunem os comerciantes $\mathrm{e}$ os agentes de comércio, para concertar ou cumprir as operações mercantis constantes desta secção (secção I do título V), denominar-se-ão Bôlsas de Comércio".

Há que distinguir, como fazem os comercialistas, no gênero Bôlsas de Comércio, as espécies Bôlsa de Merca dorias (Produktenbörse) e Bôlsa de Valores (Fondsbörse). Ao passo que as primeiras, como diz LoRenzo BENITo, são instituições criadas para facilitar a circulação das mercadorias, as segundas o são para facilitar a circulação dos valores mobiliários ${ }^{8}$. Constitui a moderna

(6) J. GARRIGUES, obra e local citados.

(7) Operaciones de Bolsa, vol. I, p. 52.

(8) Manual de Derecho Mercantil, Madrí, 1929. 
Bôlsa de Valores um exemplo frisante de organismo destinado à realização de operações em massa, fenômeno que caracteriza o direito comercial de nossos dias.

4. Focalizando especificamente o modo de constituição das Bôlsas de Valores, verificamos que há dois sistemas principais adotados pelas legislações: o liberal e o restritivo, conforme os Governos permitam livremente a criação de Bôlsas a qualquer pessoa com capacidade jurídica ou, ao contrário, se reservem o direito de criá-las ou de autorizá-las ${ }^{9}$. Em verdade, tendo em vista a importância de que se revestem, para a coletividade, as funções atribuídas às Bôlsas de Valores, hoje em dia não se discutem a conveniência e a licitude da intervenção governamental, em maior ou menor grau, na organização e no funcionamento dessas Bôlsas ${ }^{10}$.

Apontam-se como seguindo o sistema liberal a Inglaterra, os Estados Unidos, a Argentina e a Bélgica, onde as Bôlsas são instituídas e mantỉdas por sociedades privadas; adotam, ao contrário, o sistema tutelar do Estado a França, Portugal e a Áustria ${ }^{11}$.

5. Em consonância com êsses sistemas, podem-se distinguir duas classes de Bôlsas de Valores: oficiais e privadas. Bôlsas oficiais são aquelas cuja constituição e funcionamento estão submetidas à aprovação estatal; constitui modêlo clássico dêsse grupo a Bôlsa de Paris, criada por Decreto de 24 de setembro de $1724\left(^{(11-\mathrm{A})}\right.$. Bôlsas pri-

(9) Rodrigues SAStRe, obra citada, vol. I, p. 63.

(10) J. X. CARvalHo DE MENDonÇA, no seu "Tratado", vol. VI, parte II, n. 1.590-1.592, manifesta-se contra a intervenção do Estado nas Bôlsas, invocando, a propósito, as exposições de motivos dos Códigos Belga e Argentino, em prol da liberdade das Bôlsas. Forçoso é convir, no entanto, que a situação mudou muito, após a última guerra.

(11) J. X. Carvalho DE Mendonça, Tratado, vol. VI, parte II, n. 1.589 , nota 1, p. 288 .

(11-A) Sôbre a organização da Bôlsa de Paris, ver Geonge RIPERT, Traité Élémentaire de Droit Commercial, Paris, 1948, ns. 1.6391.680 , p. 614 e segs.; JeAn Escarra, Cours de Droit Commercial, Paris, 1952, ns. $1.436-1450$, p. 1.017 e segs. 
vadas ou livres, por outro lado, são aquelas criadas independentemente de ato estatal e mantidas por pessoas jurídicas de direito privado, sociedades civis ou comerciais; dêsse tipo são as Bôlsas de Londres e Nova Iorque, cujas atividades, não obstante, são objeto de minuciosa regulamentação.

O Stock Exchange de Londres é uma organização privada, revestindo a natureza de sociedade anônima, submetida, porém, a severa regulamentação; durante largo período, foi o principal mercado de títulos do mundo.

O Stock Exchange ou Bôlsa de Nova Iorque originouse de um acôrdo entre corretores de fundos públicos, firmado em 17 de maio de 1792; embora possuindo estatutos, é uma associação livre, sem escopo lucrativo, não constituída como uma sociedade comercial ordinária, à qual estão filiados 1.375 corretores. O título de sócio do Stock Exchange é adquirido por compra, variando o preço de acôrdo com o volume dos negócios. É administrado por uma comissão composta de 32 membros, os quais, com exceção do presidente e de três representantes públicos, são eleitos pelos sócios ${ }^{12}$.

A Bôlsa de Comércio de Buenos Aires, que compreende várias câmaras gremiais e mercados, entre êles o de títulos e câmbio, foi fundada em 20 de novembro de 1854 como associação particular, funcionando, a partir de 1890 , como sociedade anônima, integrada por 250 "comissionistas" ou corretores de títulos e câmbios ${ }^{1 ?}$ ?

\section{Capítulo II}

6. O Código Comercial Brasileiro de 1850 não empregou a palavra "bôlsa". No art. 32, referiu-se tão sòmente à Praça do Comércio, que definiu como sendo "não só o local, mas também a reunião dos comerciantes, capi-

(12) Haroldo G. Moulton, obra citada, p. 297-298.

(13) ERnesto Barbosa Tomanik, Origem dos Mercados Abertos, na Revista da Bôlsa, agôsto de 1949, p. 5. 
tães e mestres de navios, corretores e mais pessoas empregadas no comércio". Acrescentou, no art. 33, que "o resultado das negociações que se operarem na praça determinará o curso do câmbio e o preço corrente das mercadorias, seguros, fretes, transportes de terra e água, fundos públicos, nacionais ou estrangeiros, e de outros quaisquer papéis de crédito, cujo curso possa ser anotado".

Embora o nosso Código de Comércio, como observou J. X. Carvalho de Mendonça ${ }^{14}$, não salientasse a sinonímia estabelecida pelo Código Comercial Português de 1833, no art. 97, entre praça do comércio e bôlsa, tem-se definido usualmente, entre nós, a Bôlsa como sendo o lugar onde se reunem os homens de negócio ${ }^{15}$.

$\mathrm{O}$ artigo 68 do Decreto $\mathrm{n}$. 648, de 10 de novembro de 1849, que regulou a profissão de corretor, já estatuía o seguinte: "Os corretores reunir-se-ão na mesma casa que serve agora de Praça do Comércio, cujo regime econômico e policial continuará a cargo da comissão da mesma Praça" Após o Código Comercial, o Decreto n. 806, de 26 de julho de 1851, que estabeleceu o Regimento dos Corretores da Praça do Rio de Janeiro, dispunha no art. 42: "A casa da Praça do Comércio é o único lugar competente para a reunião dos corretores" Do mesmo modo, o art. $10^{\circ}$ do Decreto n. 6.132, de 4 de março de 1876 , preceíuava o seguinte: "Nos edifícios destinados para Praça do Comércio haverá um lugar especial, separado e elevado, onde, à vista do público, se reunirão os corretores de fundos, quando tiverem de propôr e efetuar transações".

Encontramos a palavra "bôlsa" usada, entre nós, pela primeira vez, no Regimento Interno da Junta de Corretores da Praça do Rio de Janeiro de 12 de abril de 1877, expedido nos têrmos do art. 40 do Decreto n. 806, de 1851, cujo art. $10^{\circ}$ rezava: "A Bôlsa é o lugar no salão da

(14) Tratado de Direito Comercial Brasileiro, 3. ${ }^{a}$ ed., vol. VI, parte II, Rio de Janeiro, 1939, n. 1.583, pg. 280.

(15) JosÉ FERREIRA BoRges, Dicionário Jurídico-Comercial, 2. ed., Porto, 1896, verbetes Bôlsa de Comércio e Praça. 
Praça do Comércio ou da Associação Comercial, destinado às operações de compra e venda de títulos pủblicos, de ações de bancos e companhias, de valores comerciais e finalmente de metais preciosos".

Desde a promulgação do Código Comercial de 1850, que, no art. 32, segunda alínea, declarou que a Praça do Comércio estaria sujeita à polícia e inspeção das autoridades competentes, e, na terceira alínea, outorgou ao govêrno a faculdade de marcar, em regulamento, tudo quanto respeitasse à polícia interna das mesmas praças e mais objetos a elas concernentes, sempre se entendeu, entre nós, que "sem autorização oficial não podiam as bôlsas funcionar, cabendo ao govêrno estabelecê-las onde o desenvolvimento do comércio as reclamasse" ${ }^{16}$.

7. Na República, a legislação consagrou a expressão "bôlsa", a partir do Decreto n. 1.359, de 20 de abril de 1893, de autoria de Didimo da Veiga, que, no art. 98, se referiu à Bôlsa, conceituando-a nos mesmos têrmos do Regimento acima transcrito. Esse diploma, no art. $1 .^{\circ}$ atribuiu ao cargo de corretor de fundos a natureza de ofício público, provido, nos têrmos do art. $4 .^{\circ}$, por nomeação do Presidente da República, mediante decreto expedido pelo Ministro da Fazenda. Tais disposições foram reproduzidas pelas leis posteriores.

E bem de ver que, refletindo as origens corporativas do instituto, durante o Império e nos primórdios da República, os corretores de fundos públicos (como os corretores de navios, de mercadorias e gerais) eram obrigados a matricular-se nos Tribunais do Comércio, em 1875 substituídos pelas Juntas Comerciais, a cuja fiscalização se submetiam. Sòmente com o advento da Lei n. 354, de 16 de dezembro de 1895, passaram os corretores de fundos públicos do Distrito Federal, organizados em corporação sob a égide de uma Câmara Sindical, a depender do Minis-

(16) J. X. CaRvalho DE MEndonça, Tratado, vol. VI, parte II, n. 1.589, p. 289 . 
tério da Fazenda. Em 1897, editou-se o Decreto n. 2.475, de 13 de março dêsse ano, aprovando o Regulamento dos Corretores de Fundos Públicos da praça da Capital Federal, cujas disposições, na maioria, ainda se acham em vigor.

A primeira referência, em diploma federal, às Bôlsas estaduais, encontra-se no Decreto n. 24.275, de 27 de junho de 1934.

O estatuto básico das Bôlsas de Valores do país, no entanto, é o Decreto-lei n. 1.344, de 13 de junho de 1939, completado pela Lei n. 2.146, de 29 de dezembro de 1953; nêsses dois diplomas consubstanciam-se as diretrizes básicas de nosso direito de bôlsa, juntamente com o regulamento baixado com o Decreto n. 2.475, de 1897 .

Observa-se, em nossa legislação bolsista, a influência marcante das İeis francesas, de tal modo que se pode dizer que as nossas Bôlsas tiveram o seu modêlo na Bôlsa de Paris.

Por fim, o Decreto-lei n. 9.783, de 6 de setembro de 1946, obrigou tôdas as sociedades por ações a requererem à Bôlsa de Valores mais próxima de sua sede a cotação de suas ações e obrigações ao portador.

Do exame dessa extensa legislação, lacunosa e fragmentária, evidencia-se a necessidade da elaboração de um Código de Bôlsas, que regule, de modo sistemático, a complexa matéria bolsista, que constitui capítulo dos mais importantes do moderno direito comercial, compreendendo a organização das Bôlsas, a disciplina das atividades dos corretores e seus auxiliares e a regulamentação das operações de bôlsa.

8. Foi em 1892 que primeiramente se cogitou de criar uma Bôlsa Oficial de Títulos em São Paulo, sob os auspícios da Associação Comercial de São Paulo. O passo inicial para o reconhecimento oficial da profissão de corretor foi dado pelo Decreto estadual n. 224, de 22 de dezembro de 1894, que instituiu uma tabela de corretagens. 
Data, porém, da Lei estadual n. 479 , de 24 de dezembro de 1896, a oficialização dos cargos de corretóres de fundos públicos, nas praças de São Paulo e Santos, para cujo provimento foi o Govêrno autorizado a fazer as nomeações. Essa lei foi regulamentada pelo Decreto n. 454, de 7 de junho de 1897, que organizou a corporação dos corretores de fundos públicos da praça de São Paulo e criou a respectiva Câmara Sindical. Êsse diploma, no art. 76, conceituou a Bôlsa da mesma maneira que o art. 98 do Decreto federal n. 1.359, de 1893: “A Bôlsa é o lugar, no salão da Praça do Comércio ou onde o Secretário da Fazenda designar

Os Decretos estaduais ns. 1.125 , de 20 de abril, e 1.134, de 12 de maio de 1903, dispuzeram a respeito da Bôlsa de Fundos Públicos de Santos.

Convém lembrar que os Regimentos Internos da Bôlsa de Valores de São Paulo, de 1905, 1928 e 1944, foram aprovados por atos do Secretário da Fazenda. As tabelas de emolumentos das Câmaras Sindicais e de corretagens foram sempre aprovadas por diplomas legislativos, (lei n. 951 , de 26 de outubro de 1905), ou por atos do Secretário da Fazenda. O número de corretores nas Bôlsas de São Paulo e Santos, desde o início, foi limitado por atos governamentais, e a nomeação dos corretores de fundos sempre dependeu de nomeação do Govêrno.

A Lei estadual n. 2.165, de 22 de dezembro de 1926, Instituiu a Caixa de Garantia e Previdência dos corretores de fundos públicos de São Paulo ${ }^{16-A}$. Em 1935, pelo art. 16, letra "e" da Lei estadual n. 2.479, de 13 de dezembro, toi mudado o nome da entidade para "Bôlsa Oficial de Valores de São Paulo", que passou a ser considerada como instituto semi-autônomo, diretamente subordinado ao Secretário da Fazenda do Estado.

O Regimento Interno da Bôlsa Oficial de Valores de São Paulo, aprovado por ato do Secretário da Fazenda, de

(16-A) A gestão do patrimônio da Caixa foi regulamentada pelo Decreto estadual n. 34.592, de 27 de janeiro de 1959 . 
14 de dezembro de 1944, no art. $1 .^{\circ}$, definiu-a como "entidade incumbida da efetivação, registro e contrôle das operações sôbre títulos da dívida pública e particular e câmbio". No parágrafo único dêsse mesmo art. $10^{\circ}$ esclareceu, todavia, que a Bôlsa "constituiu-se pela reunião de corretores de fundos públicos, no pleno exercício de suas funções, representando, pelo menos, um têrço da classe".

Pelo Decreto estadual n. 20.047, de 7 de dezembro de 1950, foi dividido o fundo de reserva da Caixa Comum de Garantia e Previdência em dois fundos distintos; o fundo de garantia (compreendendo $70 \%$ da receita da Caixa) e o fundo de previdência, ou pecúlio (abrangendo $30 \%$ das receitas). O Decreto n. 20.047 foi, contudo, revogado expressamente pelo art. 34 do Decreto n. 34.592, de 27 de janeiro de 1959, que estabeleceu normas para a gestão patrimonial da Caixa Comum.

\section{Capítulo III}

9. Grandes controvérsias tem suscitado o problema da conceituação da natureza institucional das Bôlsas de Valores, em nosso direito. Estudos e pareceres têm procurado resolver a questão, chegando, contudo, a resultados diversos.

A definição da natureza jurídica das Bôlsas de Valores é, sem dúvida, fundamental, pois da colocação dessa premissa defluirão, irresistivelmente, inúmeras conclusões, que dizem respeito, entre outros aspectos, à gestão financeira, à tutela administrativa e à condição jurídica do pessoal das Bôlsas.

Impõe-se, portanto, como ponto de partida, a análise da natureza jurídica da Bôlsa de Valores de São Paulo, para defini-la como pessoa jurídica, ou não, e, no caso afirmativo, se se trata de pessoa jurídica de direito público ou de direito privado, e ainda, na primeira das hipóteses, se reveste as características de autarquia ou entidade paraestatal típica. Como problemas paralelos, dever-se-á, tam- 
bém, indagar se a Bôlsa de Valores constitui repartição pública, lato sensu, ou estabelecimento de utilidade pública.

10. A insuficiência patente de nossa legislação bolsista, aliada à equivocidade da palavra "bôlsa", que, como vimos, é empregada em vários sentidos, são os principais fatôres dos debates havidos a propósito da natureza juridica das Bôlsas de Valores.

Deixando de lado as acepções econômicas da expressão "bôlsa", como sejam a de mercado (reunião periódica de comerciantes e corretores com o fito de concluirem operações sôbre valores mobiliários ou mercadorias), de pregão (complexo de operações realizadas durante uma sessão), ou de curso ou cotação (estado das operações em dado momento), as quais se referem à própria atividade bolsista, considerada in se, só nos resta focalizar três perfis jurídicos do conceito de Bôlsa ${ }^{17}$ :

a) o aspecto subjetivo, ou seja, a Bôlsa encarada como pessoa jurídica, de direito público ou de direito privado, capaz de direitos e obrigações na ordem civil;

b) o aspecto objetivo ou patrimonial, quer dizer, a Bôlsa considerada como estabelecimento, ou complexo de bens (lugar, edifício, móveis, utensílios, livros), que são os instrumentos necessários para o exercício, pelos corretores colegiados, das atividades bolsistas;

c) o aspecto corporativo, ou seja, a Bôlsa vista como instituição, ou a própria corporação dos corretores, seus auxiliares e empregados, formando um núcleo social organizado, em função de um objetivo econômico comum, que, no caso particular da Bôlsa de Valores, seria a realização, registro e publicidade das operações sôbre títulos da dívida pública e particular e câmbio.

(17) Adotamos como modêlo, no desenvolvimento do tema, as idéias expedidas por ALBERTo ASQUINI sôbre o conceito de "emprêsa", no magistral trabalho Profili dell'impresa, na Rivista del Diritto Commerciale, Milão, 1943, vol. $41,1 .^{\mathrm{a}}$ parte, n. 1, p. 1 e segs. 
Equacionando dessa forma o problema, poderemos examiná-lo em tôda amplitude, e chegarmos, afinal, a uma conclusão, baseando-nos, para tanto, principalmente nos textos de nosso direito positivo.

11. Uma questão que desde logo se coloca é a de saber a quem cabe a competência legislativa, no tocante às Bôlsas estaduais: se à União, se aos Estados.

Compete à União, em caráter privativo e exclusivo, legislar sôbre direito comercial e instituições de crédito (Constituição Federal, art. 5. ${ }^{\circ}$ XV, letras "a" e "k"), reconhecendo-se aos Estados apenas a faculdade de dispôr sôbre a organização administrativa de suas instituições bolsistas, dentro dos limites marcados pela legislação federal. Com efeitọ, entre as matérias relacionadas no art. 6. ${ }^{\circ}$ da Magna Carta, em relação às quais é admitida a legislação estadual supletiva ou complementar, não se incluem as recém mencionadas.

A perquirição a respeito da natureza jurídica da Bôlsa de Valores de São Paulo, dessa forma, deve conter-se nos princípios que orientaram os diplomas federais que formam a base de nosso direito de bôlsa: o regulamento baixado com o Decreto n. 2.475, de 13 de março de 1897 . o Decreto-lei n. 1.344, de 13 de junho de 1939, e a Lei n. 2.146, de 29 de dezembro de 1953.

12. Não se cuidou, de início, em nossa legislação, de conceituar a Bôlsa como instituição; sempre se partiu da definição e regulamentação da profissão de corretor, para, em função desta, atingir o conceito de Bôlsa. Asseverou J. X. Carvalho de Mendonça, com acêrto, que "a história das bôlsas é a história dos corretores. A legislação daquelas encontra-se envolta na dêstes" ${ }^{17-A}$.

$\mathrm{O}$ art. $1^{\circ}$ do Decreto federal n. 1.359 , de 20 de abril de 1893, declarou constituir o cargo de corretor de fundos um ofício público. Reproduzindo êsse preceito, o art. $2 .^{\circ}$

(17-A) Tratado, vol. VI, parte II, n. 1.593, p. 294. 
do Decreto federal n. 354, de 16 de dezembro de 1895, e o art. $3 .^{\circ}$ do Regulamento aprovado pelo Decreto federal n. 2.475, de 13 de março de 1897, estatuiram que os corretores de fundos públicos, na Capital Federal, seriam nomeados pelo Presidente da República, mediante decreto expedido pelo Ministro da Fazenda. De igual modo, em nosso Estado, a Lei n. 479, de 24 de dezembro de 1896, no art. $10^{\circ}$ e o Regulamento aprovado pelo Decreto n. 454 , de 7 de junho de 1897 , nos arts. $1 .^{\circ}$ e $3 .^{\circ}$, atribuiram o caráter de ofício público ao cargo de corretor de fundos, competindo ao Presidente do Estado o seu provimento, em decreto expedido pelo Secretário da Fazenda.

Aliás, o próprio Código Comercial, no art. 52, estabelecera que "os livros dos corretores que se acharem sem vício nem defeito e regularmente escriturados... terão fé pública." Atribuiu, dest'arte, expressamente, a qualificação de ofício público ao mister desempenhado pelos corretores. Essa conceituação não se alterou na legislação subsequente.

13. Não encontramos, em nenhum passo da nossa tumultuária legislação federal sôbre corretores e bôlsas de fundos públicos, um só dispositivo que permita reconhecer na "Bôlsa" uma entidade dotada de capacidade de reger por si os próprios interêsses, ou, em outras palavras, dotada de personalidade jurídica, quer de direito público, quer de direito privado.

As leis se referem sempre aos corretores, isoladamente, ou às Juntas de Corretores ou Câmaras Sindicais, como órgãos da corporação dos corretores, para atribuirlhes direitos, deveres e funções.

O Decreto n. 648, de 10 de novembro de 1949, previa, como expressão orgânica do colégio de corretores, a Junta dos Corretores, à qual competia, nos têrmos do artigo 58, além do exercicio do poder disciplinar, a função precipua de assinar o curso oficial do câmbio e dos fundos e valores negociados. Funções idênticas foram atribuídas à Câmara 
Sindical pelo art. 87 do Decreto 1.359 , de 20 de abril de 1893, cabendo ao síndico, na forma do artigo 89, alínea "a", representar a Câmara Sindical e a corporação dos corretores perante o Govêrno. as autoridades constituídas e em juízo".

$\mathrm{O}$ art. $7 .^{\circ}$ do Decreto n. 354 , de 16 de dezembro de 1895, atribuiu, outrossim, à Câmara Sindical, a organização do regimento interno da Bôlsa e da corporação de corretores e da tabela dos emulumentos que êles devem perceber, tudo sujeito à aprovação do Ministério da Fazenda, bem como poderes para autorizar, proibir e suspender a negociação e a cotação dos valores particulares e impôr as multas previstas em lei, com recurso para o Ministro da Fazenda. A matéria de competência da Câmara Sindical foi também explanada, em têrmos semelhantes, pelo art. 73 do Regulamento dos Corretores de Fundos Públicos da Capital Federal, aprovado pelo Decreto 2.475, de 13 de março de 1897, e, mutatis mutandis, pelo artigo 73 do Regulamento dos Corretores de Fundos Públicos da Praça de São Paulo, aprovado pelo Decreto estadual n. 454, de 7 de junho de 1897.

14. O simples exame da legislação desautoriza, pois, a qualificação da Bôlsa como pessoa jurídica, de direito público ou de direito privado. Tôdas as vêzes que as leis empregam a expressão "bôlsa", fazem-no em sentido instrumental, querendo com ela significar o lugar onde se exerce a atividade profissional dos corretores e o conjunto de bens necessários para o exercício dessa atividade.

Mesmo que se veja na Bôlsa uma instituição, sob o aspecto corporativo, considerada como uma reunião de pessoas, organizada em função de um objetivo comum, em última análise essa instituição se confunde com a própria corporação dos corretores, cuja expressão orgânica é a Câmara Sindical.

Tem inteiro cabimento, a esta altura, relembrar as palavras de Asquini, na tradução de Sílvio Marcondes MACHADO: "Instituição é tôda organização de pessoas - 
voluntária ou coacta - fundada sôbre uma relação de hierarquia e de cooperação entre seus membros, em função de um objetivo comum.. O reconhecimento de uma organização de pessoas como instituição, não significa personalização - nem perfeita, nem imperfeita - da organização. Instituição e pessôa jurídica operam em direções diferentes. A outorga de personalidade jurídica a uma organização de pessôas tem essencialmente o escopo de atribuir, a um sujeito diverso dos indivíduos singulares, as relações jurídicas externas da organização. O reconhecimento de uma organização de pessoas, como instituição, implica sòmente no reconhecimento de um determinado modo de ser das relações internas, entre os seus componentes, em vista de um fim comum. É certo que, quando uma organização de pessoas é elevada pelo Direito ao grau de pessôa jurídica, o fenômeno da personalidade pode absorver o da instituição também nas relações internas, tal como nas sociedades. Mas a vida de uma organização de pessoas, como instituição, é uma vìda interna que, por si mesmo, não acarreta, absolutamente, personalização" 18 .

15. Tem sucedido, algumas vêzes, empregar-se a palavra "bôlsa", como entidade personificada, por evidente êrro de técnica (verbi gratia, o Decreto-lei n. 9.783, de 6 de setembro de 1946, que dispõe sôbre a admissão, para cotação em Bôlsa, de ações ou obrigações ao portador). De acôrdo com a sistemática de nosso direito, deve-se entender, nestes casos, que o vocábulo "Bôlsa" aí está, por metonímia, no lugar da "Câmara Sindical", que é o órgão diretivo da corporação dos corretores.

Isto não conduz, necessàriamente, à personalização da Câmara Sindical, porquanto, externamente, subsistem as relações jurídicas entre os corretores e os terceiros que com êles contratam.

(18) AsquiNI, obra e loc. cits., ns. 12 e 13, p. 16 e 18, apud Sílvio MARCONDES MACHADo, Limitação da Responsabilidade de Comerciante Individual, São Paulo, 1956, n. 45, p. 144. 
A própria responsabilidade civil e criminal da Câmara Sindical se resolve, em última análise, na responsabilidade pessoal dos membros que a compõem, como, aliás, dispunha expressamente o art. 150, segunda alínea, do Decreto n. 1.359 , de 20 de abril de 1893, verbis: "A Câmara Sindical é responsável pela exatidão dos preços cotados no mercado de câmbio e de fundos públicos. A fálta de exação na cotação acarreta para os membros da referida Câmara a incursão no crime de falsidade, a perda da totalidade da fiança e a destituição". Êsse preceito não foi reproduzido pelo Decreto n. 2.475, de 13 de março de 1897, o qual estabeleceu, porém, para a hipótese, no art. 151, alínea "c", a pena de perda de metade da fiança para os membros da Câmara Sindical.

A lei fundamental sôbre bôlsas de valores, em nosso país, que é o Decreto-lei n. 1.344, de 13 de junho de 1939, foi, aliás, incisiva ao estabelecer, no art. $5 .^{\circ}$, que:

"As bôlsas de valores e as respectivas câmaras sindicais e caixas de garantia e previdência não respondem, direta ou indiretamente, pela liquidação das operações."

16. São esclarecedoras, a propósito, as seguintes considerações do Dr. Mozart Emygdio Pereira:

"Embora a legislação brasileira de Bôlsas seja decalcada sôbre a francesa, não há o princípio da solidariedade de todos, pela responsabilidade funcional de cada um.

$\mathrm{Na}$ França, dentro do espírito de unidade corporativa, criou-se um fundo solidário, entre todos os componentes da corporação, para garantir a efetivação, em casos determinados, das obrigações de qualquer um dêles. Esta solidariedade expressa estabeleceu-se em 1819, por uma convenção, a qual, em 1898, passou de um 
compromisso espontâneo a uma imposição de lei, devida à reorganização do mercado financeiro de Paris.

$\mathrm{Na}$ Inglaterra, a responsabilidade pelas liquidações circunscreve-se ao broker diretamente interessado, ou à sociedade, partnership, de que êle faça parte, não acarretando a responsabilidade solidária dos demais membros da Bôlsa de Londres.

O sistema brasileiro, neste sentido, distanciou-se do francês, assemelhando-se ao inglês. Adotou a responsabilidade individual e não a corporativa, pela solidariedade" ${ }^{19}$.

Ora, se a titularidade das relações jurídicas externas da corporação dos corretores continua a incidir sôbre os indivíduos singulares que a compõem, visto que as operações de bôlsa se estabelecem entre comitentes e corretores, não há que falar em personalidade jurídica dessa corporação. Do mesmo modo, a Câmara Sindical, como órgão diretivo da corporação dos corretores, existe principalmente para efeitos internos: só em matéria mui restrita pode-se falar em relações externas da Câmara Sindical, e mesmo assirn como órgão através do qual se exerce uma competência que é privativa e inerente ao ofício de corretor, mas que, pela própria natureza das coisas, só pode ser exercida colegiadamente.

A investidura, na pessoa do síndico, da representação judicial da Câmara Sindical e da corporação dos corretores, não altera a situação, pois a outorga do poder de representação não implica, necessàriamente, a personalidade jurídica, tal como sucede com a massa falida e a herança (Cód. de Processo Civil, art. 85).

(19) A Bôlsa e o Direito, in Suplemento do Repertório de Legislação de Bôtsa e Banco, São Paulo, 1952, p. 51. Ver, ainda, a propósito, o parecer do Prof. Tullio Ascarelli, in Ensaios e Pareceres, São Paulo, 1952, p. 241-249. 


\section{Capítulo IV}

170 moderno direito administrativo admite várias formas de execução dos serviços públicos, que se graduam desde a administração direta, pelo próprio Estado, até as formas mais descentralizadas, que se aproximam da administração privada. Entre as formas de descentralização por serviço ou institucional podem ser mencionadas as autarquias administrativas. Além disso, pode o Estado cometer o desempenho de serviços públicos a entidades privadas, como as sociedades de economia mista, as emprêsas concessionárias, os estabelecimentos de utilidade pública, etc.

As profundas transformações sofridas pelo direito público, em nossos dias, têm exigido, como imperativo de sobrevivência das próprias instituições políticas, econômicas e sociais, a adoção de um conceito mais amplo de serviço público e das entidades às quais incumbe sua execução. Assim, no que se refere às estruturas administrativas, não é possível enquadrar em moldes rígidos as novas entidades surgidas para o cumprimento de variadas atribuições no campo econômico-social. Não mais se discute, atualmente, a possibilidade de entidades privadas assumirem a gestão de serviços ou funções públicas.

No Brasil, como assinalou Themístocles Brandẽo CAvalcanti, o sistema da Constituição de 1946 "é extremamente flexível e admite um conjunto de providências onde grande é a colaboração da atividade privada e dos métodos privados na execução de serviços que vivem sob o contrôle estatal" ${ }^{20}$.

(20) Tratado de Direito Administrativo, $3 .^{\mathrm{a}}$ ed., 1956, vol. II, p. 44. Veja-se, a respeito, o brilhante parecer de DARIo DE ALMEIDA MAGALHÃES, sôbre a natureza jurídica da Ordem dos Advogados do Brasil, inserto na Revista de Direito Administrativo, vol. 20, p. 340. 
18. A multiplicidade dos encargos do Estado tornou necessária a descentralização funcional, mediante a atribuição de personalidade jurídica a certos serviços, que, dessa forma, adquirem maior ou menor grau de autonomia, de acôrdo com a lei institucional de cada um dêsses entes, chamados autárquicos. Não passa, a criação de autarquias, como observou Francisco Campos, de "um processo técnico pelo qual o Estado descentraliza o serviço, dotando-o de órgão e patrimônio próprios" ${ }^{21}$.

Podemos, assim, dizer, com THEmístocles Brandão Cavalcanti que "em sua expressão mais peculiar, portanto, as chamadas autarquias administrativas são serviços públicos descentralizados, que se destacaram do conjunto da administração estatal, para se organizarem de acôrdo com as necessidades dos serviços que visam executar" ${ }^{22}$.

Em monografia que se tornou clássica na matéria, escreveu Trto Prates da Fonseca que "a autarquia administrativa, a que os franceses denominam estabelecimento público personificado, apresenta duas notas características: - constitui sempre um serviço público, e por aí se distingue dos estabelecimentos de utilidade pública, que são serviços privados; tem personalidade jurídica" ${ }^{23}$.

Em outras palavras, o principal caráter da autarquia é súa personalidade jurídica: é um serviço público especial personalizado. "A existência da autarquia", aduz Tiтo Prates, "deriva da lei, que lhe concede o poder de decisão, pelo qual agirá como pessoa jurídica" ${ }^{24}$.

Constituindo a personalidade (ou seja, a aptidão, reconhecida pela ordem jurídica a alguém, para exercer direitos e contrair obrigações ${ }^{25}$, uma qualidade outorgada pela lei, pensamos, com Tito Prates, que só é possível a

(21) Pareceres, II série, 1936, p. 310.

(22) Tratado cit., vol. II, p. 89.

(23) Autarquias Administrativas, São Paulo, 1935, p. 19.

(24) Obra citada, p. 38.

(25) Clovis Bevilaqua, Código Civil Comentado, 6. a ed., 1940, vol. I, p. 168; LUIZ DA CUNha Gonchalves, Tratado de Direito Civil, 1. ${ }^{\text {a }}$ ed. bras., São Paulo, 1955, vol. I, n. 29, p. 189. 
criação de autarquias através de lei, não se podendo induzir dos fatos a personalidade jurídica caracterizadora da entidade.

Não é por outro motivo que Santi Romano define a autarquia como "uma forma específica da capacidade de direito público, ou melhor, a capacidade de dirigir os seus próprios interêsses, não obstante a intervenção do Estado" 26 .

19. Discorrendo a propósito dos elementos jurídicos dos serviços públicos, lembra Tito Prates da Fonseca a lição de GASTon JÈze, para quem devem ser invocados como critérios jurídicos para reconhecimento da existência, em determinado caso, de serviço público propriamente dito :

a) o estabelecimento de encargos especiais, destinados a assegurar o funcionamento do serviço;

b) o poder de percepção de impostos ou taxas pròpriamente ditas, para garantir o funcionamento do serviço;

c) a criação do monopólio de exploração;

d) a origem, ou seja, a iniciativa da criação do estabelecimento.

$\mathrm{E}$ assinala que não constituem sinais decisivos:

a) a intervenção de um ato de autoridade pública para a fundação de um estabelecimento;

b) a aprovação por um agente público dos regulamentos de regime e serviço interno de um estabelecimento;

c) a nomeação, pelo govêrno, de certos administradores;

d) a necessidade de aprovação administrativa para todos ou certos atos de administração praticados:

e) a sujeição da contabilidade do estabelecimento ao contraste fiscal público ${ }^{27}$.

(26) Corso di Diritto Amministrativo, 3. ${ }^{a}$ ed., 1937, p. 84.

(27) Autarquias Administrativas, pg. 36-37. 
Nessa mesma ordem de idéias, podemos assentar os requisitos integrantes da autarquia, segundo a lição autorizada de Rafael Bielsa, para quem os elementos constitutivos essenciais das autarquias são de ordem intrínseca e extrínseca.

Os elementos intrínsecos sâo:

$10^{\circ}$ - a personalidade jurídica e consequente competência específica de direito público;

$2 .^{\circ}$ - a realização de função administrativa ou prestação de um serviço público;

$3 .^{\circ}$ - a afetação de recursos próprios.

Os elementos extrínsecos são:

$10^{\circ}$ - a criação legal ou emanação de um poder autònomo, que fixa as regras fundamentais da administração autárquica;

$2 .^{\circ}$ - a tutela administrativa, de intensidade variável de caso para caso ${ }^{28}$.

20. Cuidando de estabelecer normas para a organização, funcionamento e fiscalização das entidades autárquicas, vários diplomas legislativos as definiram.

Assim, o Decreto-lei n. 6.016, de 22 de novembro de 1943, que dispõe sôbre a imunidade de bens, rendas e serviços das autarquias da União, Estados e Municípios, dispôs no art. 2. ${ }^{\circ}$ : "Considera-se autarquia, para efeito dêste decreto-lei, o serviço estatal descentralizado, com personalidade de direito público, explícita ou implìcitamente reconhecida por lei".

A Lei n. 830, de 23 de setembro de 1949, que reorganizou o Tribunal de Contas da União, no art. 139, estatuiu:

(28) Derecho Administrativo y Ciencia de la Administración, 2." ed., 1929, vol. I, p. 247, apud Tito Prates DA Fonseca, Direito Administrativo, Rio de Janeiro, 1939, p. 239. 
“Consideram-se entidades autárquicas:

a) o serviço estatal descentralizado, com personalidade jurídica, custeado mediante orçamento próprio, independente do orçamento geral;

b) as demais pessoas jurídicas especialmente instituídas por lei, para execução de serviços de interêsse público ou social, custeados por tributos de qualquer natureza, ou por outros recursos oriundos do Tesouro".

Ainda recentemente, no âmbito estadual, o Projeto de lei n. 1.124 , de 1953 , concernente ao regime orgânico de contrôle administrativo das entidades autárquicas, conceituou as autarquias, no art. $1^{\circ}$, parágrafo ủnico, da seguinte forma: "Considera-se autarquia a entidade criada por lei estadual, com personalidade jurídica de direito público e afetação de patrimônio, ou de recursos, para a prestação de um serviço público ou o exercício de função administrativa".

Ocorre, pois, em tôdas as definições legais, a mesma constante da personalidade jurídica de direito público, como principal característica das autarquias.

21. Como doutrinou Mario RoTond com relação à azienda, a determinação da natureza jurídica de um instituto não pode ser feita senão através da dedução de regras do direito positivo, nunca por indução de princípios juridicos preconcebidos ${ }^{29}$. Também para Arnaldo DE VALLES é ao legislador que pertence fixar as condições por que uma entidade pode ser reconhecida como pertencente a uma dada categoria de entidades públicas ${ }^{30}$.

Aplicando os critérios preconizados pela doutrina ao caso especial das Bôlsas de Valores e Câmaras Sindicais, verificamos que, em absoluto, podem tais entidades ser

(29) Trattato di Diritto dell'Industria, Padua, 1935, n. 30, 75.

(30) Elementi, n. 112, p. 81-82. 
caracterizadas como autarquias institucionais, ou como pessoas jurídicas de direito público.

Não existe, em nosso direito positivo, qualquer texto erigindo as Bôlsas de Valores em entidades autárquicas, providas de personalidade jurídica. O mesmo sucede com as Câmaras Sindicais dos corretores de fundos públicos.

o Síndico, que é o presidente da Bôlsa e o representante legal da Câmara Sindical e da corporação dos corretores, não é nomeado livremente pelo Govêrno, como acontece geralmente nas autarquias, mas é anualmente eleito, dentre os corretores, em assembléia geral realizada a 10 de janeiro, por fôrça do art. 33 do Decreto-lei federal $n$. 1.344, de 13 de junho de 1939 .

Se bem que não se possa falar pròpriamente em funções administrativas, cometidas às Bôlsas de Valores, não cabe dúvida de que aos corretores, singular e coletivamente, delega a lei uma série de atribuições que, pelo relevante interêsse que assumem para a coletividade, revestem a natureza de serviços públicos, ainda mais que são exercidos em caráter de privilégio, e submetidos ao contrôle e fiscalização do poder público. Não se trata, porém, de uma tutela administrativa pròpriamente dita, que se exerceria através do exame, pelo Estado, do mérito, da oportunidade e da conveniência dos atos praticados na Bôlsa, o que não ocorre de nenhum modo.

As Bôlsas não são desmembramentos de serviços estatais diretos pré-existentes; ao contrário, correspondem a atividades e práticas mercantis que surgiram espontâneamente e se foram gradativamente expandindo e aperfeiçoando no decorrer do tempo. As Bôlsas existem em função do desenvolvimento econômico e financeiro: têm sempre existência de fato, antes de serem criadas ou reconhecidas por lei. Podem ser reconhecidas, regulamentadas e fiscalizadas pelo Estado; contraria, porém, a natureza das coisas a sua criação arbitrária pela lei. "Bôlsas, para serem bôlsas, devem surgir espontâneamente do co- 
mércio. Não se pode criá-las sem base. Não há leis que as escorem" 31 .

22. O principal argumento que se alinha contra a conceituação das Bôlsas de Valores como autarquias, no direito pátrio, diz respeito, contudo, à ausência de patrimônio próprio.

Realmente, não se pode conceber a existência de uma autarquia, pessoa jurídica de direito público, sem a afetação de recursos próprios, que constituam um patrimônio apto a solver as obrigações legalmente assumidas.

A doutrina clássica, de AUBRY e RAU, indissolùvelmente liga a noção de patrimônio à de personalidade, definindo o patrimônio como o conjunto dos direitos e das obrigações de uma pessoa; logo, não é possivel a existência de patrimônio sem sujeito, e de pessoa sem patrimônio. É de recordar, a propósito, a definição lapidar do Conselheiro Lafayette: "Patrimônio é o acêrvo de todos os nossos haveres; constitui uma universalidade de direito, um todo composto de bens diversos reunidos sob a unidade da pessoa a que pertence" 32 .

$\mathrm{Na}$ autarquia, há necessàriamente um patrimônio, porque existe a pessoa jurídica, sob cuja fôrça unitiva se forma a universalidade.

23. Ora, para que possam as Bôlsas atingir suas finalidades, indispensável se torna a outorga de recursos suficientes. Em verdade, o Decreto n. 2.475, de 13 de março de 1897, no art. 73 , letra "c" declara competir à Câmara Sindical a organização da tabela de emolumentos que devem perceber os corretores, sujeitando-a à aprovação do Ministro da Fazenda. No mesmo sentido dispóe o artigo de igual número do Decreto estadual n. 454, de 7 de junho de 1897, sendo, porém, a aprovação do Secretário da Fazenda.

(31) J. X. Carvalho DE MendonçA, Tratado, vol. VI, $3 .{ }^{2}$ parte, n. 1.592, p. 292-293.

(32) Direito das Coisas, 5. ${ }^{\mathrm{a}}$ ed., 1943, § 34, nota 3, p. 97. 
Sucede, no entanto, que todos os recursos afetados pelo Estado à Bôlsa integram-se, não no patrimônio da própria Bôlsa, no da Câmara Sindical ou no da corporação dos corretores, mas, nos têrmos da lei, às Caixas Comuns de Garantia e Previdência, dos Corretores de Fundos Públicos, criada na praça de São Paulo pela Lei estadual n. 2.165, de 22 de dezembro de 1926 e na do Rio de Janeiro pela Lei Federal n. 106, de 23 de outubro de 1935.

Estabelece o $\operatorname{art.~} 3 .^{\circ}$ da Lei estadual n. 2.165, citada:

“Art. 3. ${ }^{\circ}$ - A Caixa Comum será constituída pela universalidade do patrimônio da corporação dos corretores e compreenderá:

a) - todos os valores, dinheiro e títulos públicos e particulares que possua a Bôlsa de Fundos Públicos;

b) - o produto de todos os emolumentos cobrados pela Bôlsa, quer dos corretores, quer das partes interessadas, de acôrdo com a tabela aprovada pelo Govêrno;

c) - o produto das taxas cobradas pela posse dos corretores oficiais, prepostos e adjuntos;

d) - a renda dos bens da Bôlsa;

e) - o produto das multas, donativos, subvenções e quaisquer outras contribuições;

f) - o produto das corretagens e comissões que a Câmara Sindical vier a receber por negócios e operações que realizar"

À Caixa de Garantia e Previdência, cujas finalidades são a de tornar efetiva a responsabilidade dos corretores nos seus atos funcionais, formar um pecúlio para subsistência do corretor em caso de invalidez completa e amparar sua família em caso de morte (art. $4 .^{\circ}$ ), conferiu a lei personalidade jurídica (art. $60^{\circ}$ da Lei n. 2.165, citada). 
Até os saldos orçamentários resultantes da liquidação do exercício financeiro pertencem à Caixa, nos têrmos do art. 44 do Decreto-lei n. 1.344, de 13 de junho de 1939. O Decreto estadual n. 20.047, de 7 de dezembro de 1950, mandou levar $70 \%$ do saldo do exercício financeiro ao fundo de garantia e $30 \%$ ao fundo de previdência, em partes iguais a cada corretor ${ }^{32-\mathrm{A}}$. Quando o fundo de previdência (pecúlio) do corretor atingir o limite máximo, fixado em lei federal (atualmente $\operatorname{Cr} \$ 350.000,00$ ), o restante será levado integralmente ao fundo de garantia.

É lógico que, se a universalidade do patrimônio e das rendas líquidas da Bôlsa é afetada à Caixa de Garantia e Previdência, sendo sua aplicação prefixada em lei (art. 12 da Lei n. 106, de 1935; art. 11 da Lei estadual n. 2.165, de 1926; art. 66 do Decreto estadual n. 5.894, de 26 de abril de 1933), nada resta à Bôlsa de Valores, à Câmara Sindical ou à Corporação dos Corretores para constituir os patrimônios respectivos. Esta conclusão, aliás, afinase com o que acima afirmamos, pois, sendo o patrimônio a emanação da personalidade, se à Bôlsa de Valores negamos a qualidade de pessoa jurídica, òbviamente não pode ter patrimônio, como realmente não tem.

Diante do exposto, não há senão concluir que a Bôlsa de Valores e a Câmara Sindical dos corretores, embora sujeitas a uma disciplina legal sui generis, não são entidades autárquicas, providas de personalidade jurídica de direito público ${ }^{33}$.

(32-A) Revogado pelo Decreto n. 34.592, de 27 de janeiro de 1959, (33) No mesmo sentido são os pareceres do professor THEMistoCles Brandão Cavalcanti, datado de 2 de fevereiro de 1957, que vê nas Bôlsas órgãos privados, de colaboração com o poder público; e do Dr. Aloysio GonZaga Romeirio, no processo G-27.035/56. Contra: os pareceres do DR. MozART EMygdio PereirA, na Revista da Bôlsa, março de 1953 , p. 8-10 e abril de 1953, p. 8-10; Dr. José BAPtista NETo, Porto Alegre, 31 de agôsto de 1950; professor VICENTt Ráo, de 18 de outubro de 1956; Dr. JoÃo MANUEL CARNEIRo DE LACERDA, de fevereiro de 1957; AROLDo MOREIRA, Bôlsas de Valores, artigo na Revista. de Finanças Públicas, n. 195 (maio-junho de 1957), p. 22-26, n. 196 (julho-outubro de 1957), p. 7-13. 
24. Refletindo a perplexidade do legislador ante as deficiências de nosso direito de bôlsa, as leis estaduais, de início, classificaram a Bôlsa Oficial de Valores entre os institutos autônomos ou semi-autônomos diretamente subordinados ao Secretário da Fazenda (Lei estadual n. 2.479 , de 13 de dezembro de 1935, art. 16, letra "e"; Decreto estadual n. 10.197, de 17 de maio de 1939, arts. $2 .^{\circ}$ e $5 . .^{\circ}$ ).

A Lei estadual n. 3.703, de 7 de janeiro de 1957, no art. $1 .^{\circ}$, novamente afirmou a subordinação da Bôlsa ao Secretário da Fazenda, embora de acôrdo com o art. $4 .^{\circ}$ da mesma lei, continue ela a reger-se pela legislação que lhe é peculiar.

No entanto, a subordinação à autoridade administrativa não qualifica necessàriamente a entidade como autárquica, tanto assim que inúmeras são as entidades em que o Estado tem interêsses econômico-financeiros e que revestem a natureza de sociedades de economia mista ou de instituições subvencionadas, dotadas de personalidade de direito privado. Não existe dúvida que a Administração Pública pode ter interêsses ligados a entidades privadas, e o Decreto estadual n. 27.186, de 7 de janeiro de 1957, isso reconhece, quando no art. $1 .^{\circ}$ enumera entre as entidades públicas ou privadas cuja responsabilidade para defesa dos interêsses do Estado atribui à Secretaria da Fazenda, as Bôlsas Oficiais de Café e Mercadorias de Santos, de Valores de São Paulo e de Valores de Santos.

O Decreto estadual n. 31.288, de 13 de março de 1958 , por sua vez, regulamentando a Lei n. 3.703, de 1957, assim dispõe no parágrafo único do art. $1 .^{\circ}$ :

"Parágrafo único - Constituem atribuições da Secretaria (da Fazenda), que centraliza, no limite de sua competência legal, a orientação dos negócios financeiros do Estado:

a) - exercer tutela sôbre as autarquias estaduais, no que tange às suas atividades Rconômico-financeiras, sem prejuízo da exercida 
pelos órgãos competentes, quanto ao cumprimento de suas atividades;

b) - zelar pelos interêsses da Administracão Públicas, de qualquer forma ligados às entidades públicas ou privadas abaixo relacionadas:

$$
\begin{aligned}
\text { V - } & \text { Bôlsa Oficial de Café e Mercadorias de } \\
& \text { Santos, } \\
\text { VI - } & \text { Bôlsa Oficial de Valores de São Paulo, } \\
\text { VII - } & \text { Bôlsa Oficial de Valores de Santos". }
\end{aligned}
$$

Como se vê, a própria legislação distingue entre a tutela exercida pela Secretaria da Fazenda sôbre as autarquias estaduais, e o contrôle que emprega em relação às entidades públicas ou privadas, entre as quais se inclui a Bôlsa Oficial de Valores de São Paulo.

\section{Capítulo V}

25. Seguindo o modêlo francês, a lei brasileira conferiu aos corretores de fundos públicos a natureza de exercentes de verdadeiros ofícios públicos, dando-lhes, outrossim, o caráter de notários, pelo cunho de autenticidade, legalidade e solenidade que imprimem às operações em que intervêm.

O Código Comercial Brasileiro de 1850, no art. 35, incluiu os corretores entre os agentes auxiliares do comércio. $O$ art. $1 .^{\circ}$ do Decreto n. 1.359 , de 20 de abril de 1893 , contudo, asseverou peremptòriamente que "o cargo de corretor de fundos constitui um ofício público". Essa conceituação foi reproduzida pelo artigo $1 .^{\circ}$ do Decreto n. 354, de 16 de dezembro de 1895 , pelo art. $10^{\circ}$ do Regulamento aprovado pelo Decreto n. 2.475, de 13 de março de 1897, e pelo art. $1 .^{\circ}$ do Regulamento aprovado pelo Decreto estadual n. 454, de 7 de junho de 1897 . Note-se, ainda, que 
o art. 62 do Decr. n. 2.475, de 1897, estatui que as certidões extraídas dos livros dos corretores terão fôrça de instrumento público, para prova dos contratos respectivos.

No entanto, os corretores, embora desempenhando funções de interêsse público, agem em nome próprio e no seu peculiar interêsse, o que basta para distinguí-los dos agentes públicos, pois êstes, como acentuou o professor Osvaldo Aranha Bandeira de Mello, "agem sòmente em nome e no interêsse do Estado, sendo as suas atividades sempre imputadas a êle como próprias. Por essa razão, o poder público não responde, neste caso, pelo dano ocasionado a terceiros, ao passo que responde, sempre, quando as atividades são exercidas pelos seus agentes ${ }^{34}$.

Não há dúvida, diante de nossa legislação, que os corretores oficiais não são agentes ou funcionários públicos, não obstante exerçam ofício qualificado como público, uma vez que as atividades que desenvolvem dizem respeito ao interêsse da coletividade. No dizer do autor citado, "na sistemática do nosso direito administrativo, se catalogam tais atividades como formas de exercício privado de ofícios ou serviços públicos" 35

É claro que, pela natureza mesma de suas funções, os atos dos corretores oficiais estão sujeitos à fiscalização e ao contrôle do poder público, em grau mais intenso do que se se tratasse do exercício de simples atividade privada, indo até à gestão dos próprios negócios dêsses profissionais.

26. De tudo quanto se tem escrito em nosso país a respeito da natureza jurídica dos corretores oficiais, sobreleva, a nosso vêr, o trabalho do professor Osvaldo Aranha Bandeira de Mello, que versou exatamente sôbre êsse tema. Nesse estudo, ficou demonstrado, de maneira conclusiva,

(34) Natureza jurídica dos corretores oficiais, São Paulo, 1943, p. 8, separata da revista Direito, vol. viII, ano de 1942.

(35) Ibidem, pág. 9. 
que, em nosso direito, os corretores oficiais não são funcionários públicos, e sim comerciantes, embora investidos de funções públicas ${ }^{36}$.

É óbvio que a Administração Pública, delegando a particulares o desempenho de serviços de vital importância para a coletividade, reserva-se o exercício de estrita atividade controladora, que se manifesta quer pela limitação do número e pela nomeação dos corretores, quer pela regulamentação e fiscalização de seus atos, quer pela aplicação de penalidades aos infratores do regulamento. Aos livros dos corretores oficiais, escriturados em devida forma, confere a lei fé pública, como que lhes outorgando a categoria de notários comerciais (Decreto 2.475, de 13 de março de 1897, art. 56). Por êsses motivos é que se considera ofício público o dos corretores.

No exercício de atribuições delegadas pelo Estado, os corretores oficiais agem, ou isoladamente (intermediação na compra e venda de fundos públicos e particulares, metais preciosos e câmbio) ou colegiadamente (admissão de valores particulares à cotação e fixação do curso oficial do câmbio, dos valores e das espécies), constituindo-se, para tanto, em corporação, sujeita ao contrôle e fiscalização da Câmara Sindical.

Temos, assim, que a Câmara Sindical é o órgão da corporação dos corretores, através da qual se exerce a competência atribuída por lei coletivamente aos corretores. Em outras palavras, se os corretores são oficiais públicos, a Câmara Sindical é uma serventia coletiva, à qual jncumbe o desempenho das atribuições previstas na lei para a corporação dos corretores.

(36) No mesmo sentido são as opiniões dos mestres: J. X. CARvalHo DE Mendonç, Tratado de Direito Comercial Brasileiro, vol. I, n. 343 , p. 489-490; vol. II, n. 313, p. 292; WALDEMAR FERREIRA, Tratado de Direito Mercantil Brasileiro, 3. ${ }^{\text {a }}$ ed., 1948, vol. III, p. 360. No direito francês: JEAN EscarRa, Cours de Droit Commercial, Paris, 1952, n. 1.439, p. 1.019; GeoRges RIPert, Traité Elémentaire, Paris, 1948, n. 1.658, p. 620; AlBert WahL, Précis de Droit Commercial, Paris, 1922 , n. 1.591 , p. 565 . 
Explica-se dessa forma a circunstância de haver o Decreto federal n. 21.584, de 21 de setembro de 1932, previsto que, das decisões da Câmara Sindical autorizando, proibindo ou suspendendo a cotação e a negociação de valores na Bôlsa, caberá recurso, sem efeito suspensivo, para o Tribunal de Justiça, o qual seguirá o processo estabelecido para a discussão e julgamento das apelaçóes cíveis.

27 Em nosso regime administrativo, a colaboração dos particulares com o poder público pode revestir modalidades diversas. É o caso, exatamente, dos corretores que, reunidos na Bôlsa, sob a superintendência da Câmara Sindical, desempenham um munus público.

Afastada a qualificação das Bôlsas de Valores como organizações autárquicas, cabe indagar se existe alguma categoria jurídica em que poderiam ser enquadradas.

Mrahoud, citado por Tito Prates da Fonseca, afirma que, "se um estabelecimento não pode invocar em favor de sua personalidade uma lei geral ou especial, dever-se-á, segundo o caso, considerá-lo como simples estabelecimento privado (que poderá mesmo ser considerado de utilidade pública por uma lei) ou como uma dependência direta da administração geral" ${ }^{37}$ Abandonada a segunda hipótese, por inaplicável ao caso, resta apenas a conceituação da Bôlsa de Valores como estabelecimento de utilidade pública.

Êste é o conceito que, a nosso vêr, melhor se coaduna com os textos de lei e a doutrina, no tocante à Bôlsa de Valores. Trata-se, com efeito, "de satisfazer, por meio de uma entidade distinta da autoridade pública, necessidades de interêsse geral, por meio de um processo que não é o de direito público" 38 . Isto é, exatamente, o que se denomina estabelecimento de utilidade pública, que é uma

(37) Personnalité Morale, $2^{\text {a }}$ ed., vol. I, p. 365, apud Tito PRATES DA FONSECA, Autarquias Administrativas, p. 38.

(38) Tito Prates da Fonseca, Autarquias Administrativas, p. 147. 
forma de cooperação da atividade privada na administração pública, mediante a outorga de direitos, obrigações e privilégios, que lhe traçam um regime jurídico peculiar.

Como elucida Trto Prates, "a utilidade pública é uma qualidade que, pelo reconhecimento do Poder Público, pode afetar uma das entidades enumeradas no $n$. I do art. 16 do Código Civil, enquanto que a autarquia é uma entidade de direito público criada pelo Estado" ${ }^{39}$. Notese, ainda, que, entre as pessoas jurídicas de direito privado a que se refere o art. 16, n. I do Código Civil figuram as associações de utilidade pública. Assim, caso se reconheça personalidade jurídica à corporação dos corretores, não haverá dificuldade em classificá-la entre as pessoas jurídicas de direito privado.

Na França, onde fômos buscar o modêlo de nossas Bôlsas, os corretores "formam uma companhia que têm personalidade jurídica, mas não constitui um estabelecimento público" (ou autárquico, para nós).

Existe, por último, um argumento de ordem legal, que patenteia, de modo irrecusável, ser a Bôlsa um órgão privado, de colaboração com o Poder Público.

Estatui o artigo $10^{\circ}$ da Lei n. 2.146, de 29 de dezembro de 1953: "As Bôlsas Oficiais de Valores são órgãos auxiliares dos poderes públicos, na fiscalização dos lançamentos de emissão de títulos, por subscrição pública".

Ora, se as Bôlsas (ou melhor, as Câmaras Sindicais) são reputadas órgãos auxiliares do Estado para determinado fim, é porque, certamente, não se integram na Administração Pública, centralizada ou descentralizada, só lhes restando enquadrar-se entre as pessoas jurídicas de direito privado.

(39) Georges RIPERT, Traité Élémentaire, n. 1.655, p. 619, perbis: "Les agents de change exerçant leurs fonctions dans une bourse à parquet forment une compagnie qui a la personnalité morale, mais ne constitue pas un établissement publique" No mesmo sentido, AlbarT Wahl, Précis, n. 1.606, p. 570. 


\section{Capítulo VI}

28. Uma vez que a Bôlsa de Valores não é repartição pública ou autarquia administrativa, os seus servidores não estão submetidos ao estatuto dos funcionários públicos, nem tampouco têm as prerrogativas e vantagens aos mesmos asseguradas por lei. $\mathrm{Na}$ verdade, só os que percebem pelos cofres do Estado ou de entidade pública, e recebem a investidura de uma autoridade pública, podem ser qualificados como funcionários públicos.

Ora, os servidores da Bôlsa não são nomeados pelo Govêrno e nem são estipendiados pelo Tesouro, o que é suficiente para descaracterizá-los como funcionários públicos. Pelos motivos expostos, também não podem ser considerados funcionários autárquicos. Assim, aplica-selhes a legislação federal que disciplina a relação de emprêgo privado, ou seja, o contrato de trabalho, com as modificações introduzidas por regimentos e leis especiais, que lhes confere um regime jurídico próprio (Decreto-lei n. 1.344, de 13 de junho de 1939, art. 58, verbis: "Segundo suas possibilidades, cada Bôlsa dará assistência a seus empregados, que deverão ter pensão e aposentadoria").

Dispõe o atual Regimento Interno da Bôlsa Oficial de Valores de São Paulo, aprovado por ato de 14 de dezembro de 1944, no art. $265, \S 50^{\circ}$ que: "Os casos omissos nêste Regimento Interno e relativos ao funcionalismo administrativo da Bôlsa serão resolvidos segundo o disposto no Estatuto dos Funcionários Públicos Civis do Estado, aplicado subsidiàriamente".

No entanto, como observa Themístocles Brandão CavaLcaNTI, "não basta a aplicação subsidiária do estatuto dos funcionários públicos para dar à relação de emprêgo a categoria de emprêgo público" ${ }^{40}$. Trata-se de simples

(40) Parecer de 2 de fevereiro de 1957, sôbre a situação jurídica dos servidores das Bôlsas de Valores: Contra: parecer do Dr. Mozart Emygdio Pereira, de 13 de abril de 1953. 
opção por um regime legal, feita, aliás, de maneira imprópria.

Fôsse a Bôlsa uma repartição pública ou uma autarquia, e desnecessária seria a disposição expressa do art. 58 do Decreto-lei n. 1.344, acima transcrito, que visa a assegurar a seus servidores um mínimo de direitos e garantias. E trata-se, é bem de ver, de preceito de lei federal, aplicável a tôdas as Bôlsas de Valores do país.

29. Uma das manifestações do poder de vigilância exercido pelo Estado em relação às Bôlsas de Valores diz respeito ao contrôle financeiro, aliás, restrito, que se exerce:

a) pela prévia aprovação da tabela de emolumentos percebidos pela Bôlsa e pelos corretores (Decreto n. 2.475, de 13 de março de 1897, art. 73, letra "c"; Decreto estadual n. 454, de 7 de junho de 1897, art. 73 , letra "c").

b) pela aprovação dos orçamentos anuais e dos balanços de receita e despesa e de ativo e passivo (Lei estadual n. 2.844, de 7 de janeiro de 1937 , arts. $3 .^{\circ}$ a $5 .^{\circ}$; Decreto estadual n. 8.499, de 20 de agôsto de 1937).

Além dêsse contrôle externo, exercido pelo Estado, existe um contrôle interno, exercitado por órgão da própria Bôlsa, no caso, a Comissão de Contabilidade, eleita todo ano conjuntamente com a Câmara Sindical, nos têrmos do art. $6 .^{\circ}$ da Lei n. 106, de 23 de outubro de 1935, e do art. $33, \S 10^{\circ}$ do Decreto-lei n. 1.344 , de 13 de junho de 1939. A essa Comissão compete examinar mensalmente a contabilidade e opinar sôbre a proposta orçamentária e a prestação de contas anual.

O contrôle externo da gestão financeira da Bôlsa é, contudo, limitado rigorosamente aos têrmos da lei, que não parece autorizar o chamado contrôle de legitimidade, por meio do qual se verifica o quantum das despesas e a equidade de sua aplicação, a conveniência ou oportunidade das mesmas, ainda mais que não se trata de entidade autárquica. A fiscalização do Estado deve fazer-se 
sentir a priori, principalmente quando da aprovação das tabelas de emolumentos e taxas e das propostas orçamentárias.

Não cabe, outrossim, ao Tribunal de Contas julgar as contas da Câmara Sindical. O Tribunal de Contas do Éstado de São Paulo teve ensejo de pronunciar-se a respeito da natureza jurídica da Bôlsa Oficial de Valores de São Paulo, no processo n. TC-2182/53, em sessão de 16 de outubro de 1953, quando decidiu não constituir aquêle órgão uma entidade autárquica, não se enquadrando, portanto, na sua jurisdição, nos precisos têrmos da Lei estadual n. 1.666 , de 31 de julho de 1952. Os principais fundamentos dessa decisão repousam nos fatos de não ter a Bôlsa capacidade jurídica de direito público, nem ter sido especialmente criada por lei, requisitos êsses indispensáveis para a caracterização das autarquias ${ }^{41}$

30. As Câmaras Sindicais têm o direito de cobrar taxas e emolumentos para a manutenção de seus serviços. Regulam o assunto o Decreto n. 2.475, de 1897, o Decretolei n. 1.344, de 1939 e a legislação estadual correspectiva. Há a distinguir, porém, entre os emolumentos cobrados pelos atos praticados pela Câmara Sindical e as corretagens percebidas pelos corretores de fundos públicos, pela mediação nas operações e negociações referidas na lei.

Compete à Câmara Sindical, na forma dos arts. 73, letra "c" e 162 do Decreto n. 2.475, de 1897, e de idênticos preceitos do Decreto estadual n. 454, de 7 de junho de 1897, organizar a tabela dos emolumentos que devem perceber os corretores, sujeitando-os à aprovação do Secretário da Fazenda. A tabela em vigor foi expedida pela Resolução n. 2/52, que foi aprovada pelo Secretário da Fazenda.

(41) Votaram com o relator, Ministro Rodrigues ALVES SobrINho, os Ministros Genesio de Almeida Moura, OLIVEIRA RIBEmo, SYNesio Rocha, José Romeu FrRraz e Costa MEIRA, e contra o Ministro MaXimiliano XIMENES. 
As taxas e emolumentos cobrados em razão de atos e operações praticados pela Bôlsa de Valores, e que figuram como receita ordinária nas previsões orçamentárias, são os seguintes:

1 - Emolumentos da Câmara Sindical

2 - Certidões de cotação de títulos

3 - Registro de alvarás

4 - Admissão de títulos ou valores à cotação

5 - Taxa de registro de operações de câmbio

6 - Taxa de conservação no quadro de títulos cotados na Bôlsa

7 - Taxa de publicação de resumos de balanços na Revista da Bôlsa

8 - Taxa de arquivamento de documentos

9 - Taxa de exame de documentos.

10 - Fundo da Biblioteca - Taxa adicional de $20 \%$.

Já as corretagens devidas aos corretores são fixadas percentualmente sôbre o valor das operações e negociações em que intervêm, e revestem, iniludivelmente, o caráter de preço de um serviço de natureza privada.

31. Quando da última alteração da tabela de emolumentos da Bôlsa de Valores de São Paulo, em 1952, foi suscitada a questão da ilegalidade das taxas cobradas pelos atos praticados pela Câmara Sindical (não dos emolumentos cobrados pelos corretores), por revestirem um autêntico caráter tributário, e, conseguintemente, só poderem ser estabelecidas por lei ${ }^{42}$.

Alegou-se, então, que, havendo o Decreto-lei n. 9.783, de 6 de setembro de 1946, conferido à Câmara Sindical atribuições que refogem à simples prestação de serviços

(42) Cf. parecer do Dr. Alcides JORGE Costa, do Departamento Jurídico da Federação das Indústrias do Estado de São Paulo. 
de intermediação, próprios dos corretores, para enquadarse na categoria de serviços de uso obrigatório por particulares, qualquer resolução da Câmara Sindical dispondo sôbre a cobrança de taxas por êsses serviços careceria de fundamento legal, quer por falta de lei autorizadora, quer porque essa fixação seria de competência do legislador, não podendo ser delegada a outrem.

As taxas (a que se equiparam os emolumentos) são definidas pelo art. $1 .^{\circ}, \S 2 .^{\circ}$ do Decreto-lei 2.416 , de 17 de julho de 1940, como sendo o tributo exigido como remuneração de serviços específicos prestados ao contribuinte ou postos à sua disposição, ou ainda as contribuições destinadas ao custeio de atividades especiais do Estado ou do Município, provocadas por conveniências de caráter geral ou de determinados grupos de pessoas. Mas as taxas ou emolumentos são cobrados ùnicamente pelo poder público, e são, necessàriamente, instituídos por lei e autorizados pelo orçamento (Constituição Federal, art. 141, § 34).

Envolvendo as funções cometidas pelo Decreto-lei n. 9.783 à Câmara Sindical típica delegação do poder de polícia do Estado, as contribuições devidas pela utilização obrigatória dêsses serviços teriam caráter tributário e poderiam ser classificadas como taxas, cuja cobrança só pode ser autorizada por lei, e não por mera resolução.

Deve-se assinalar, a propósito, que as tabelas de emolumentos das Câmaras Sindicais eram outrora aprovadas por leis, como sucedeu com as leis estaduais n. 961, de 22 de dezembro de 1905 e 2.165 , de 22 de dezembro de 1926 . Daí a pretendida ilegalidade da Resolução n. 2/52, da Câmara Sindical da Bôlsa de Valores de São Paulo, a qual, embora referendada pelo Secretário da Fazenda, deveria, para elidir qualquer dúvida, ser ratificada por diploma emanado do Poder Legislativo.

O exame do problema escapa do âmbito do presente estudo; pareceu-nos, todavia, interessante assinalar as dúvidas suscitadas a êsse propósito. 
32. Assentado, como ficou, que as Bôlsas de Valores, ou as Câmaras Sindicais, não constituem entes autárquicos, providos de personalidade de direito público, as demais questões, colocadas no pressuposto dessa qualificação jurídica, desatam-se naturalmente.

É o que pensamos haver esclarecido nestas achegas para o estudo dos aspectos jurídicos da Bôlsa, ainda tão pouco conhecidos entre nós. 